\title{
Opportunity for sustainable biomass valorization to produce biochar for improving soil characteristics
}

\author{
Aysu Ulusal $^{1} \cdot$ Esin Apaydın Varol ${ }^{1}$ (D) $\cdot$ Viktor J. Bruckman ${ }^{2,3}$ (I) $\cdot$ Basak Burcu Uzun $^{1}$ \\ Received: 14 May 2020 / Revised: 14 May 2020 / Accepted: 23 July 2020 / Published online: 12 August 2020 \\ (C) The Author(s) 2020
}

\begin{abstract}
Biochar, a byproduct obtained from valorization of waste biomass, is utilized in environmental management to restore or improve soil functions where it alters chemical, physical, and biological processes. Therefore, in this study, vastly available oak sawdust was evaluated as a potential feedstock for biochar production with the aim to identify the influence of carbonization conditions on biochar characteristics. Slow pyrolysis with temperatures ranging from 400 to $600{ }^{\circ} \mathrm{C}$ and residence times from 15 to 120 min was performed. The feedstock material and resulting biochar were characterized for physical, chemical, and hydraulic properties that are significant for their ability and characteristics as a soil amendment. The pH, BET surface area, carbon content, nutrient content, alkaline functional groups, and water holding capacity increased with increasing pyrolysis temperature and residence time while biochar yield, $\mathrm{O} / \mathrm{C}$ ratio, and acidic functional groups decreased. Although the effect of holding time on biochar physicochemical properties is less significant than that of temperature, it is an essential parameter to obtain desired biochar properties. It can be concluded that pyrolysis has the potential to add value to regionally available oak sawdust on a sustainable basis and help to restore or improve essential soil functions.
\end{abstract}

Keywords Oak sawdust $\cdot$ Biomass wastes $\cdot$ Pyrolysis $\cdot$ Biochar $\cdot$ Soil amendment

\section{Introduction}

Production of value-added outputs from biomass residues is a sector of great interest as it can provide benefits from an

This paper is dedicated to our dear colleague Basak B. Uzun, who tragically deceased during the drafting of this manuscript.

Viktor J. Bruckman

viktor.bruckman@oeaw.ac.at

Aysu Ulusal

aulusal.work@gmail.com

Esin Apaydın Varol

eapaydin@eskisehir.edu.tr

Basak Burcu Uzun

bbuzun@anadolu.edu.tr

1 Department of Chemical Engineering, Faculty of Engineering, Eskișehir Technical University, 26555 Eskișehir, Turkey

2 Commission for Interdisciplinary Ecological Studies, Austrian Academy of Sciences, 1010 Vienna, Austria

3 Department of Forest- and Soil Sciences, Institute of Forest Ecology (IFE), University of Natural Resources and Life Sciences, Vienna, Peter-Jordan-Straße 82, 1190 Vienna, Austria environmental point of view. The transformation of biomass into a carbon product is becoming increasingly popular to provide a sustainable material for soil remediation [1]. Especially woody biomass, such as agricultural and forestry by-products, can be utilized as a renewable and sustainable source of biochar. Oak sawdust as a biowaste from forestry or timber industry is traditionally used as a solid fuel, but it is also an essential feedstock to produce biochar for environmental engineering [2].

Biochar is a carbon-rich, solid product of the thermochemical conversion of biomass that can be applied as a soil amendment to enhance or restore soil functions and fertility [2, 3]. The pyrolysis process represents thermal conversion of biomass in an environment of limited oxygen while representing a sustainable transformation of biomass to biochar and biofuels $[4,5]$. Because of its prominent physicochemical properties, biochar has a wide range of potential applications in various areas, such as soil conditioning, soil remediation, waste management, climate change mitigation, carbon sequestration, catalysis or activated carbon with specific materials, and energy production [6-9]. Biochar has the potential to restore soil functions as a catalyst for microbial activity and nutrient cycling [10]. By variation of pyrolysis conditions and feedstock selection, environmental properties of biochar, such as carbon content, aromaticity, pore structure, nutrient 
content, $\mathrm{pH}$, water holding capacity, and functional groups can be altered to address specific issues at a given site in any environmental setting [11].

In general, there are two main types of pyrolysis processes: slow and fast pyrolysis, depending on the residence time, temperature, and heating rate. Pyrolysis process results in both primary and secondary reactions such as dehydration, depolymerization, cleavage of glycosides, decarboxylation, decarbonylation, and debranching [12]. The primary cracking reactions lead to the release of volatile components including water vapor, $\mathrm{CO}_{2}, \mathrm{CO}$, and $\mathrm{CH}_{4}$ from the biomass structure. The secondary reactions support the formation of heavy molecules such as tar and char with increasing pyrolysis temperature. The physicochemical properties of biochar, such as surface characteristics, organic and inorganic composition, stability, and nutrient and water adsorption abilities, are mainly determined from feedstock properties and pyrolysis parameters. In particular, the driving factors are biomass characteristics and composition, such as lignin content and mineral content [13-16], pyrolysis temperature [13, 17-22], residence time [15, 23], and heating rate [10].

Among these parameters, the pyrolysis temperature is the most significant one in terms of resulting biochar properties, determining its suitability for soil amendment by altering reaction mechanisms and ecological recalcitrance [24, 25]. In general, biochar produced at high pyrolysis temperatures (> $600{ }^{\circ} \mathrm{C}$ ) is characterized by high $\mathrm{pH}$, large surface area (porosity), and higher aromaticity. On the contrary, lower process temperatures and slow heating rates result in higher char yield and greater amounts of volatiles and oxygen, and thus, it provides high electrical conductivity and cation-exchange capacity [7, 26-28]. These properties provide higher adsorption capacity and larger potential for stable carbon in the soil [29, 30]. Higher condensed aromatic $C$ contents result in a higher cation-exchange capacity for biochar as beneficial cations can interact within condensed aromatic carbon pores [31]. In addition, increasing the pyrolysis temperature leads to the reduction of easily degradable components $[26,32]$ and loss of acidic functional groups. However, fractions of degradable carbon can be desirable in certain application scenarios for stimulating microbial activity and enhancing nutrient cycles. In addition, biochar produced at low temperatures contains more unstable organic substances such as aliphatic and cellulose-type structures that promote microbial activity in soil $[6,33,34]$.

Residence time is an important carbonization condition influencing biochar physicochemical properties. Char yield and volatile matter content decrease with time and remain stable after around $1 \mathrm{~h}$. Conversely, the ash content increases with residence time. Moreover, at low $\left(300{ }^{\circ} \mathrm{C}\right)$ or high $(700$ $\left.{ }^{\circ} \mathrm{C}\right)$ pyrolysis temperatures, the residence time is more effective on ash, volatile matter, and fixed carbon than in the moderate temperature range of $450-600{ }^{\circ} \mathrm{C}$ [35]. An increase in residence time significantly increases the stability of biochar produced at low temperature $\left(350^{\circ} \mathrm{C}\right)[36]$. Long residence times produce more carbonized biochar, with a larger fraction of recalcitrant carbon and more resistance against microbial decomposition [37]. However, a clear judgment between the effects of residence time and temperature on biochar properties is difficult [38].

In this study, sawdust from oak (Quercus sp.) was used, since it is a widely available feedstock in many Mediterranean and sub-Mediterranean regions and especially in Turkey. Quercus sp. forests cover the largest area in Turkey ( $\sim 6$ million hectares, $26.34 \%$ of all forest area) [39]. Oak sawdust is a residue of the forestry, timber, and furniture industry. During the typical manufacturing of wood, approximately $12 \mathrm{wt} \%$ of sawdust is produced. Due to its firing capacity and similar characteristics with wood, it is used as fuel for combustion furnaces or gasification reactors. However, its calorific value is lower than that of high-rank coal, and therefore, it is normally combusted for only domestic heating purposes after further processes, increasing feedstock costs (pelletizing, briquetting). Upgrading this sustainable feedstock material by pyrolysis to produce a soil amendment with distinct features adds value and can generate additional income in rural areas while addressing specific soil issues and sequestering carbon. Biochar from woody feedstock material, such as oak wood, is considered suitable for soil amendment [32, 40, 41]. The current study is designed to examine and compare biochar key properties that determine its suitability for soil amendment by varying pyrolysis temperature and residence time. The structure and chemical properties of biochar are investigated by using standard analytical and instrumental techniques. The most important properties for soil restoration capability of oak wood-based biochar are discussed in this study.

\section{Materials and methods}

\subsection{Biomass feedstock origin and characterization}

Oak (Quercus sp.) sawdust was obtained from Bolu, northwestern Turkey. This region has large forest resources, and a recent report suggested that only about $50 \%$ of the annual increment is harvested at current [42]. Consequently, we assume that the provision of oak feedstock from this region likely increases and can be maintained at sustainable levels in future management scenarios. Untreated sawdust was dried at $105{ }^{\circ} \mathrm{C}$ in a laboratory oven for $24 \mathrm{~h}$ and sieved to remove large chunks. The analyses were carried out using established procedures presented in Table 1 .

The characterization tests were duplicated to ensure the reliability of results, and mean values are presented in Table 2 . 
Table 1 Characterization methods for feedstock analysis

\begin{tabular}{lll}
\hline & Parameter & Method \\
\hline Proximate analysis & Moisture & EN ISO 712:2009 \\
& Ash & ASTM E1755-95 \\
& Volatile matter (VM) & ASTM D3175-11 \\
& Fixed carbon (FC) & From difference \\
Component analysis & Cellulose & {$[43]$} \\
& Lignin (acid soluble) & {$[43]$} \\
Ultimate analysis & Extractives (alcohol-benzene soluble) & ASTM E 1690-08 \\
& C, H, N content & Elemental analyzer \\
& O content & From difference \\
& Nutrient content & Spectrometer \\
\hline
\end{tabular}

\subsection{Biochar production}

Slow pyrolysis was performed in the current study, in order to maximize solid product (biochar) output. A stainless steel fixed bed reactor with $70-\mathrm{mm}$ DI and $350-\mathrm{cm}^{3}$ volume was used, which has been used in several other studies [54, 55]. A schematic description is provided (Fig. 1). Temperature was controlled with a thermocouple that was placed inside the reactor during experiments. A proportional-integral-derivative (PID) controller ensured constant pyrolysis temperature during residence time. The reactor was subsequently allowed to cool down.

The pyrolysis experiments were conducted at 400,500 , and $600{ }^{\circ} \mathrm{C}$ under constant residence time $(30 \mathrm{~min})$ to investigate

Table 2 Proximate, ultimate, component analyses of oak wood and several wood-based biomasses from reference studies

\begin{tabular}{|c|c|c|c|c|c|c|c|c|c|c|c|c|}
\hline \multirow[t]{2}{*}{ Woody feedstock } & \multicolumn{3}{|c|}{ Proximate analysis, wt $\%$} & \multicolumn{5}{|c|}{ Ultimate analysis, wt $\%$} & \multicolumn{3}{|c|}{ Fiber analysis, wt $\%$} & \multirow[t]{2}{*}{ Reference } \\
\hline & $\mathrm{VM}^{\mathrm{a}}$ & $\mathrm{Ash}^{\mathrm{a}}$ & $\mathrm{FC}^{\mathrm{a}, \mathrm{c}}$ & $\mathrm{C}^{\mathrm{b}}$ & $\mathrm{H}^{\mathrm{b}}$ & $\mathrm{O}^{\mathrm{b}, \mathrm{c}}$ & $N^{b}$ & $\mathrm{~S}$ & Cellulose $^{\mathrm{a}}$ & Lignin $^{\mathrm{a}}$ & Hemicellulose $^{\mathrm{a}}$ & \\
\hline Oak wood & 78.52 & 0.99 & 12.43 & 46.6 & 6.4 & 46.6 & 0.4 & nd & 39.25 & 24.38 & 26.7 & This study \\
\hline Olive wood & 79.6 & 3.2 & 17.2 & 49 & 5.4 & 44.9 & 0.7 & 0.03 & $n d$ & $n d$ & nd & {$[44]$} \\
\hline Pine wood & 72.4 & 6 & 21.6 & 52.8 & 6.1 & 40.5 & 0.5 & 0.09 & $n d$ & $n d$ & $n d$ & {$[45]$} \\
\hline Pine pruning & 82.2 & 2.7 & 15.1 & 51.9 & 6.3 & 41.3 & 0.5 & 0.01 & $n d$ & $n d$ & $n d$ & {$[46]$} \\
\hline Wood & 84.1 & 0.2 & 15.7 & 49.6 & 6.1 & 44.1 & 0.1 & 0.06 & $n d$ & $n d$ & 23.15 & {$[47]$} \\
\hline Mix sawdust & 84.6 & 1.1 & 14.3 & 49.8 & 6 & 43.7 & 0.5 & 0.02 & 43.7 & 28.8 & $n d$ & {$[48]$} \\
\hline Mix sawdust & 70.4 & 1.2 & 18.5 & 48.4 & 5 & 46.3 & 0.4 & $n d$ & $n d$ & $n d$ & 22.3 & [49] \\
\hline Olive wood & $84 \pm 1$ & $3 \pm 1$ & $12.9 \pm 0.4$ & 50 & 6.4 & 41 & 1.4 & $n d$ & $n d$ & $n d$ & nd & {$[15]$} \\
\hline Pine wood & $84 \pm 1$ & $2.4 \pm 0.3$ & $13.0 \pm 0.9$ & 47 & 5.9 & 47 & $n d$ & $n d$ & 50.3 & 23.4 & $n d$ & \\
\hline Poplar wood & $81 \pm 2$ & $5 \pm 1$ & $14 \pm 2$ & 45 & 5.6 & 48 & 0.6 & nd & 49.8 & 30.3 & $n d$ & \\
\hline Wood mix (pine:spruce 5:95\%) & 77.2 & 5.7 & 17.2 & 53.7 & 6.7 & 33.9 & 0 & $n d$ & 48.4 & 23.5 & nd & {$[50]$} \\
\hline Pine wood & 73.2 & 2 & 21.6 & 49.5 & 5.9 & 44.7 & 0 & $n d$ & 41.9 & 23.1 & $n d$ & {$[36]$} \\
\hline Spruce wood & 83.5 & 0.5 & 16.1 & 48.3 & 6.3 & 44.6 & 0.4 & $n d$ & 50.8 & 27.5 & 21.2 & {$[41]$} \\
\hline Beech wood & 85.9 & $0.4-0.7$ & 13.4 & 46.9 & 6.2 & 45.9 & 0.3 & $n d$ & 45.8 & 21.9 & 31.8 & \\
\hline Birch wood & 78.7 & 0.3 & 20.9 & 48.4 & 5.6 & 45.8 & 0.2 & nd & 25.7 & 15.7 & 40 & \\
\hline Pine wood & 88.1 & 1.1 & 10.3 & $n d$ & $n d$ & $n d$ & $n d$ & $n d$ & 45.6 & 26.8 & 24 & \\
\hline Soft wood & 78.5 & $0.3-0.4$ & 11.2 & 46.1 & 6.6 & 46.6 & 0.2 & 0.1 & $n d$ & $n d$ & $n d$ & {$[51]$} \\
\hline Pine wood chips & 75.7 & 2 & 22.3 & 50.7 & 4.8 & 42.4 & 0 & nd & 52 & 12.6 & 21 & {$[52]$} \\
\hline Blackbutt (wood) & 79.5 & 1.6 & 18.9 & 48.9 & 6.6 & 44.2 & 0 & 0.3 & $n d$ & $n d$ & $n d$ & \\
\hline White oak & $n d$ & 2 & $n d$ & 50.3 & 6.4 & 43 & 0.3 & nd & 50.4 & 22.8 & 14.3 & [53] \\
\hline
\end{tabular}

\footnotetext{
${ }^{\text {a }}$ Dry basis

${ }^{\mathrm{b}}$ Dry-ash-free basis

${ }^{\mathrm{c}}$ Calculated from difference

$n d$ not detected
} 


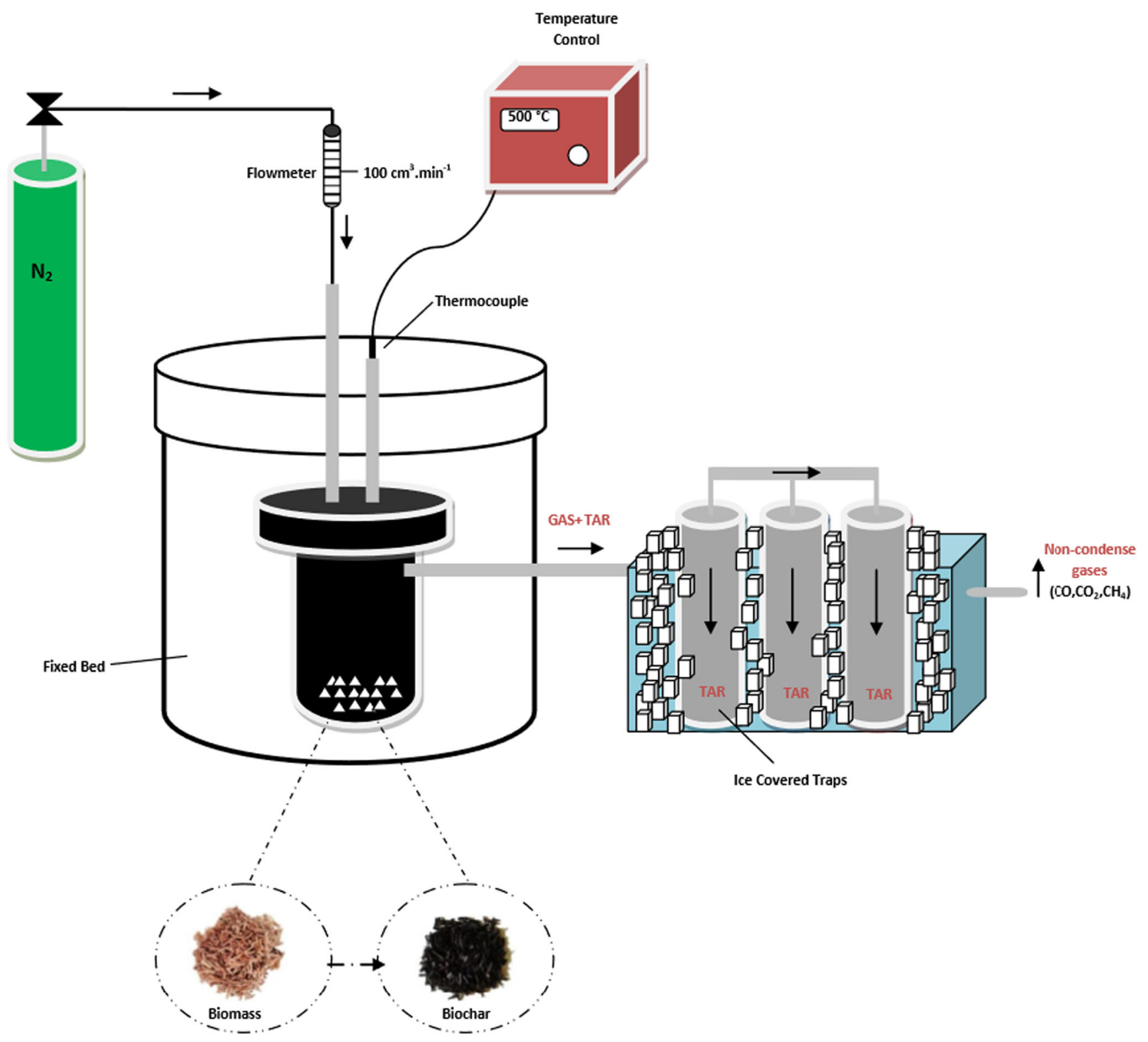

Fig. 1 Pyrolysis unit

the influence of temperature on biochar properties. Nitrogen gas flow rate was set to $100 \mathrm{~cm}^{3} \mathrm{~min}^{-1}$ which was controlled by flowmeter during pyrolysis to ensure an oxygen-limited environment. The second group of experiments, aiming at the detection of residence time effects, was carried out at $500{ }^{\circ} \mathrm{C}$ at residence times of $15,30,60$, and $120 \mathrm{~min}$. We selected this temperature since it represents an optimal range for bio-oil production, and it was shown that it is an optimal temperature for favorable biochar characteristics for soil amendment $[19,27]$. About $20.0 \mathrm{~g}$ of oak sawdust $\left(D_{\mathrm{p}}=\right.$ $1.63 \mathrm{~mm}$ ) was used for each pyrolysis batch, and the solid product was collected and stored at room temperature in a desiccator for further analysis. Each pyrolysis experiment was performed at least three times, and the average yields were calculated to confirm the reproducibility of the results.

\subsection{Characterization}

\subsubsection{Chemical composition analyses}

The proximate analysis of oak sawdust biochar was performed according to the ASTM D1762-84 standard method. We used a CHN elemental analyzer for ultimate analysis. The total nutrient content of biochar was assessed by means of ICPOES. The biochar samples were digested with $6 \mathrm{~mL}$ concentrated $\mathrm{HNO}_{3}, 2 \mathrm{~mL} \mathrm{H}_{2} \mathrm{O}_{2}(30 \%)$, and $0.4 \mathrm{~mL}$ concentrated $\mathrm{HF}$ in a $45-\mathrm{mL}$ Teflon cylinder vessel in the microwave oven according to standards DIN 22022-2, DIN 22022-7, and DIN EN ISO 17294-2/DIN EN 1483 [56]. The filtered digest was analyzed for the total concentrations of $\mathrm{K}, \mathrm{Ca}, \mathrm{Mg}, \mathrm{Na}$, $\mathrm{Al}$, and $\mathrm{Fe}$. 


\subsubsection{Pore structural characteristics}

The true density $\left(\rho_{\mathrm{s}}\right)$ is determined with a He pycnometer (Quantachrome Instruments, USA, UltraFoam ${ }^{\mathrm{TM}} 1200 \mathrm{e}$ ). Bulk density was determined according to standard ASTM E 87382. The BET surface area $\left(S_{\mathrm{BET}}\right)$ of biochar samples was determined by $\mathrm{N}_{2}$ adsorption at $77 \mathrm{~K}$ using a Quantachrome Instruments (USA), Autosorb $1 \mathrm{C}$ analyzer. Prior to the experiment, the samples were degassed at $130^{\circ} \mathrm{C}$. Total pore volume $\left(V_{\mathrm{t}}\right)$ was obtained at $\mathrm{P} / \mathrm{P}_{\mathrm{o}}=0.95$. The particle density $\left(\rho_{\mathrm{s}}\right)$ and porosity $\left(\varepsilon_{\mathrm{p}}\right)$ were calculated from the equations below $[57,58]$.

$\rho_{p}=1 /\left(V_{t}+1 / \rho_{s}\right)$

$\varepsilon_{p}=\left(\rho_{p} / \rho_{s}\right)$

The porous structure was monitored by scanning electron microscopy (SEM) using a Zeiss-SUPRA 50 VP (Carl Zeiss Microscopy GmbH, Germany) at $15 \mathrm{kV}$.

\subsubsection{Electrochemical surface characteristics}

The $\mathrm{pH}$ of biochar was measured in $0.1 \mathrm{M} \mathrm{KCl}(1: 20$, v:v) with a $\mathrm{pH}$ meter (Sartorius PP-20, Germany) after the slurry was mixed at room temperature for $20 \mathrm{~min}$. The surface functional groups were determined using a titrimetric method. The surface acidity or basicity (mmol. $\mathrm{g}^{-1}$ ) was calculated from the amount of acid or base retention on biochar [59,60]. To determine exchangeable cations, biochar was mixed with deionized water for $24 \mathrm{~h}$. Subsequently, the solutions were filtered through $0.45-\mu \mathrm{m}$ filter paper and $\mathrm{Ca}^{+2}, \mathrm{Mg}^{+2}, \mathrm{~K}^{+1}, \mathrm{Na}^{+1}, \mathrm{Fe}^{+2}$, and $\mathrm{Al}^{+3}$ contents were measured with ICP-OES. The cationexchange capacity was calculated based on the amount of cations in cmol. $\mathrm{kg}^{-1}[61]$.

\subsubsection{Hydraulic properties}

The moisture content of biochar samples was determined according to ASTM D 2016-74. To determine the water holding capacity of biochar samples, biochar was soaked with deionized water in a glass column for $24 \mathrm{~h}$ [62]. The mixture was vacuumed at 0.7 bar for $10 \mathrm{~min}$. After removing excess water, the moist biochar samples were weighed. To obtain water-free samples, the glass column was settled in the oven at $40 \pm 2{ }^{\circ} \mathrm{C}$ until reaching a constant mass [56]. The amount of water retained by biochar was defined as the difference between the biochar weight after soaking and the biochar weight after oven drying. The water holding capacity (WHC) was calculated according to Eq. 3:

WHC $(\%)=[$ water retained $(\mathrm{g}) /$ biochar mass $(\mathrm{g})]$

$$
\times 100
$$

\section{Results and discussion}

\subsection{Feedstock properties}

The properties (fiber components, proximate, ultimate analyses) of oak sawdust feedstock are presented in Table 2. Oak sawdust contains a large amount of volatile matter (78.52 $\mathrm{wt} \%$ ) and has a low ash content (less than 1\%) indicating the suitability of this feedstock material for biochar production [41]. The volatile matter and $\mathrm{C}$ content of oak wood were the lowest, while ash and fixed carbon content were higher than general. The ash content of pine, olive, and poplar wood is in the range of 2 to $6 \mathrm{wt} \%$, whereas other samples have relatively low ash contents. Several studies which used oak wood as feedstock indicated that the ash content is below $1 \mathrm{wt} \%$ [41]. The ultimate analysis revealed high contents of carbon (46.57 wt $\%$ ) and oxygen (46.55 wt\%) similar with other specific woody feedstocks which have $45-50 \% \mathrm{C}$ and $40-45 \% \mathrm{O}$. In general, cellulose content of wood-based biomass is in the range of 25.7 to $52 \mathrm{wt} \%$ while lignin content is between 12.6 and $30.0 \mathrm{wt} \%$ (Table 2). Oak sawdust also shows a similar trend with $39 \%$ cellulose content. The main elements relevant for soil nutrient provision in biomass are $\mathrm{Ca}, \mathrm{K}$, and $\mathrm{Mg}$, where a high Ca supply is typical for oak [63]. The nutrients in oak sawdust were determined as $0.74 \mu \mathrm{g} \mathrm{g}^{-1} \mathrm{Na}, 5.29 \mu \mathrm{g} \mathrm{g}^{-1}$ $\mathrm{K}, 108.8 \mu \mathrm{g} \mathrm{g}^{-1} \mathrm{Ca}$, and $1.81 \mu \mathrm{g} \mathrm{g}^{-1} \mathrm{Mg}$.

\subsection{Biochar yield}

Biochar yield was calculated on dry-ash-free basis (Fig. 2). It depends on the two limiting parameters temperature and residence time and decreased with increasing pyrolysis temperature from 30.82 to $26.35 \%$. In addition, biochar yield decreased slightly with increasing residence time from 27.90 to $27.18 \%$. Temperature was found to be more significant than residence time in this regard. Volatile components that include $\mathrm{O}, \mathrm{H}$, and $\mathrm{N}$ are being progressively removed at higher temperatures with the consequence of increasing mass loss [5]. The rate of mass loss decreased with further increasing temperature as confirmed in other studies $[64,65]$. The biochar yield decreased by $2.93 \%$ at the temperature range from 400 to $500{ }^{\circ} \mathrm{C}$, while at the range from 500 to $600{ }^{\circ} \mathrm{C}$, it decreased only by $1.54 \%$ (Fig. 2).

\subsection{Chemical composition of biochar}

Results of proximate, ultimate analyses and nutrient elements of oak sawdust biochar samples are shown in Table 3 . Pyrolysis temperature and residence time greatly affect the chemical composition of biochar. The increase in pyrolysis temperature and residence time leads to an increase in the ash, fixed carbon and carbon contents, BET surface area, and $\mathrm{pH}$, while volatile matter and $\mathrm{H}$ and $\mathrm{O}$ contents decrease. 
Fig. 2 Biochar yields at different pyrolysis conditions (filled circular marker indicates variation of temperature; empty circular marker indicates variation of residence time at $500{ }^{\circ} \mathrm{C}$ )

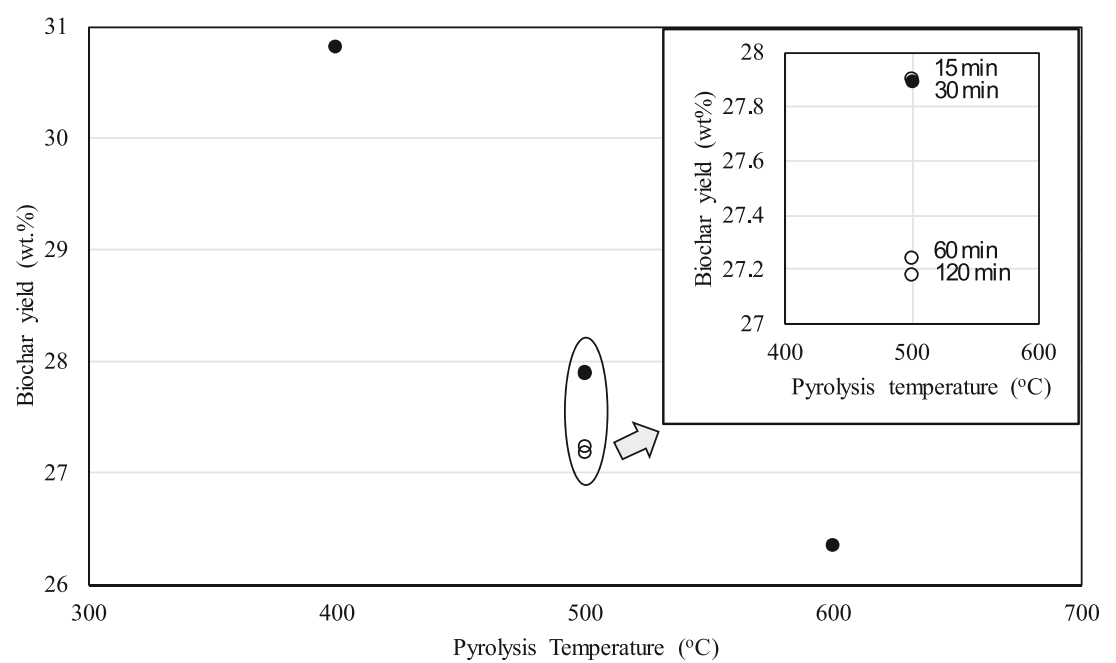

This is consistent with the reaction mechanism of thermochemical decomposition of biomass.

The content of volatile matter decreased from 15.74 to $5.14 \mathrm{wt} \%$ when the temperature increased from 500 to 600 ${ }^{\circ} \mathrm{C}$. A prolonged residence time of $120 \mathrm{~min}$ at $500{ }^{\circ} \mathrm{C}$ decreased volatile matter from 15.50 to $5.45 \mathrm{wt} \%$. An increase in temperature reduces the volatile matter content of biochar mainly due to dehydration and devolatilization reactions during pyrolysis [38]. The ash content of the obtained biochar samples increased slightly with the increase of both parameters. The most obvious difference between biomass and the resulting biochar, however, was the loss of volatile components and aggregation of fixed carbon. In addition, a sharp increase of the $\mathrm{C}$ concentration between 400 and $500{ }^{\circ} \mathrm{C}$ was observed. The $\mathrm{C}$ content increased from 81.64 to $92.35 \mathrm{wt} \%$ with a corresponding depletion of $\mathrm{O}$ and $\mathrm{H}$. The $\mathrm{C}$ concentration of biochar was also increasing with residence time due to ongoing carbonization reactions. Both $\mathrm{H} / \mathrm{C}$ and $\mathrm{O} /$ $\mathrm{C}$ ratios represent a proxy for the stability of biochar and correlate negatively with the percentage of aromatic $\mathrm{C}$ [66]. The surface chemistry behavior of biochar depends on the oxygen content due to the position of oxygen in the composition of substituted functional groups. These oxygencontaining functional groups play an important role as a driver

Table 3 Proximate, ultimate analyses and nutrient elements of oak sawdust biochar samples

\begin{tabular}{|c|c|c|c|c|c|c|c|}
\hline \multirow[t]{2}{*}{ Property } & \multicolumn{3}{|c|}{ Temperature (30 min residence time) } & \multicolumn{4}{|c|}{ Residence time $\left(500^{\circ} \mathrm{C}\right)$} \\
\hline & $400^{\circ} \mathrm{C}$ & $500{ }^{\circ} \mathrm{C}$ & $600{ }^{\circ} \mathrm{C}$ & $15 \mathrm{~min}$ & $30 \mathrm{~min}$ & $60 \mathrm{~min}$ & $120 \mathrm{~min}$ \\
\hline \multicolumn{8}{|c|}{ Proximate analysis $(\%)$} \\
\hline Moisture & 5.23 & 5.17 & 5.01 & 5.14 & 5.17 & 4.36 & 4.35 \\
\hline Ash & 4.05 & 4.32 & 4.75 & 4.33 & 4.32 & 4.55 & 4.72 \\
\hline Volatile matter & 16.79 & 15.74 & 5.14 & 15.50 & 15.74 & 5.76 & 5.45 \\
\hline Fixed carbon $^{\mathrm{a}}$ & 73.93 & 74.77 & 85.01 & 75.03 & 74.77 & 85.33 & 85.5 \\
\hline \multicolumn{8}{|c|}{ Ultimate analysis $(\%)$} \\
\hline $\mathrm{C}$ & 81.64 & 89.9 & 92.35 & 89.0 & 89.9 & 91.08 & 92.19 \\
\hline $\mathrm{H}$ & 3.44 & 2.73 & 1.81 & 2.42 & 2.73 & 2.71 & 2.93 \\
\hline $\mathrm{O}^{\mathrm{b}}$ & 14.24 & 6.68 & 5.05 & 7.94 & 6.68 & 5.27 & 3.94 \\
\hline $\mathrm{N}$ & 0.67 & 0.69 & 0.79 & 0.64 & 0.69 & 0.97 & 0.94 \\
\hline \multicolumn{8}{|c|}{ Several nutrients $\left(\mathrm{g} \mathrm{kg}^{-1}\right)$} \\
\hline $\mathrm{Ca}$ & 4.64 & 5.03 & 5.76 & 4.05 & 5.03 & 5.17 & 5.75 \\
\hline $\mathrm{K}$ & 4.49 & 5.03 & 5.35 & 4.22 & 5.03 & 5.02 & 5.11 \\
\hline $\mathrm{Mg}$ & 0.13 & 0.14 & 0.14 & 0.10 & 0.14 & 0.19 & 0.21 \\
\hline $\mathrm{Na}$ & 0.27 & 0.35 & 0.28 & 0.25 & 0.35 & 0.27 & 0.48 \\
\hline Total nutrients & 9.53 & 10.55 & 11.53 & 8.62 & 10.55 & 10.65 & 11.55 \\
\hline
\end{tabular}

${ }^{\mathrm{a}, \mathrm{b}}$ By difference 
for degradation potential [67]. Consequently, biochar produced at $600^{\circ} \mathrm{C}$ had the lowest $\mathrm{O}: \mathrm{C}$ and $\mathrm{H}: \mathrm{C}$ ratio. In addition, the lower $\mathrm{H}: \mathrm{C}$ ratio suggests that biochar produced at higher pyrolysis temperatures becomes more aromatic which corresponds to its recalcitrance in soils [68]. The aromatic carbon represents the recalcitrant fraction of biochar, while it also includes aliphatic carbon, carboxyl, and carbohydrate, which are relatively unstable and easily mineralized. These fractions are more common at low pyrolysis temperature [69]. The van Krevelen diagram of the biochar confirms that residence time is less effective for the alterations in elemental composition (Fig. 3). This indicates higher temperatures and longer residence times have a stronger occurrence of $\mathrm{C}-\mathrm{C}$ bonds compared with $\mathrm{C}-\mathrm{H}$ and $\mathrm{C}-\mathrm{O}$ bonds.

In addition to the organic fractions, inorganics in biochar, such as metal compounds or minerals, also affect the agronomic properties. For instance, the presence of carbonates may affect the carbon sequestration capacity via dissolving abiotically under acidic conditions [70]. Likewise, alkaline compounds can influence the mechanism between biochar and soil [13]. The oak sawdust biochar included various nutrient elements that are beneficial for soil fertility. In general, the concentration of each nutrient element increased with increasing temperature and residence time. Residence time was more effective than temperature in increasing $\mathrm{Na}, \mathrm{Mg}$, and $\mathrm{Ca}$ as these elements show a tendency of thermal decomposition. In terms of nutrient concentration, oak sawdust biochar produced at $500{ }^{\circ} \mathrm{C}$ and $120 \mathrm{~min}$ residence time exhibited the best conditions.

\subsection{Structural properties of biochar}

The bulk density of biochar produced at $600{ }^{\circ} \mathrm{C}$ was higher than that of $400{ }^{\circ} \mathrm{C}$, indicating a larger volume in relation to mass loss at elevated temperatures (Table 4). The true density $\left(\rho_{\mathrm{s}}\right)$ of biochar increased with temperature, since low-density disordered carbon is converted to higher-density turbostratic carbon [57]. However, the residence time had no significant effect on density. The particle density decreased with increasing pyrolysis temperature and the residence time (Table 4). At high temperature and long reaction time, more porous and less dense biochar was produced. During pyrolysis, the devolatilization of biomass leads to the final pore structure of biochar. $S_{\mathrm{BET}}$ increased significantly with increasing temperature and residence time. Biochar obtained at the highest temperature had $244.8-\mathrm{m}^{2} \mathrm{~g}^{-1}$ BET surface area and 0.112$\mathrm{cm}^{3} \mathrm{~g}^{-1}$ total pore volume. Furthermore, biochar generated at the highest residence time had the largest BET surface area $\left(368 \mathrm{~m}^{2} \mathrm{~g}^{-1}\right)$ and hence the highest porosity.

Higher porosity and consequently larger surface area are obtained at higher pyrolysis temperatures. The ongoing degradation of the aliphatic alkyl and ester groups causes the aromatic lignin matrix to be exposed at elevated temperatures. In a similar study, biochar BET surface area, microporous surface area, and total pore volume mainly increased with increasing temperature $\left(300-750^{\circ} \mathrm{C}\right)[35]$. Biochar produced at very high temperatures $\left(T>700{ }^{\circ} \mathrm{C}\right)$ has better adsorption ability due to its higher surface area and pore volume. While this might be beneficial for certain applications, lower temperatures are more effective for soil amendment, because biochar produced at temperatures of around $400-500{ }^{\circ} \mathrm{C}$ exhibits more functional groups and therefore increased CEC [7, 8].

The SEM images of the feedstock material and resulting biochar produced at $600{ }^{\circ} \mathrm{C}$ and $30 \mathrm{~min}$ residence time confirm little changes from a microscopic point of view (Fig. 4). In terms of BET surface area, the differences are obvious. However, surface morphology of the biochar is similar to the feedstock material. The majority of the macropores on biochar surface resemble the typical capillary structure of
Fig. 3 Van Krevelen diagram for oak sawdust biochar samples

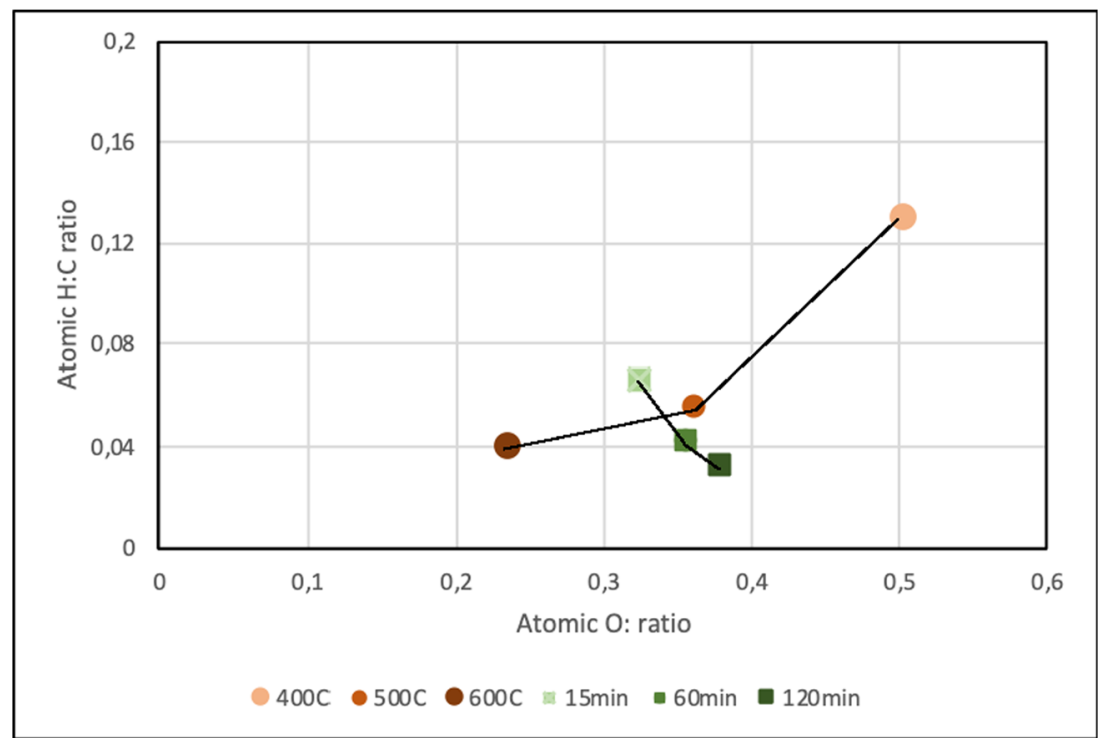


Table 4 Structural properties of biochar produced at different conditions

\begin{tabular}{|c|c|c|c|c|c|c|c|}
\hline \multirow[t]{2}{*}{ Property } & \multicolumn{3}{|c|}{ Pyrolysis temperature (30 min) } & \multicolumn{4}{|c|}{ Residence time $\left(500{ }^{\circ} \mathrm{C}\right)$} \\
\hline & $400^{\circ} \mathrm{C}$ & $500^{\circ} \mathrm{C}$ & $600^{\circ} \mathrm{C}$ & $15 \mathrm{~min}$ & $30 \min$ & $60 \mathrm{~min}$ & $120 \mathrm{~min}$ \\
\hline Bulk density $\left(\mathrm{g} \mathrm{cm}^{-3}\right)$ & 0.1926 & 0.1907 & 0.1954 & 0.1757 & 0.1907 & 0.2036 & 0.1935 \\
\hline True density $\rho_{\mathrm{s}}\left(\mathrm{g} \mathrm{cm}^{-3}\right)$ & 1.4301 & 1.5443 & 1.6069 & 1.6356 & 1.5443 & 1.6307 & 1.5647 \\
\hline Particle density $\rho_{\mathrm{p}}\left(\mathrm{g} \mathrm{cm}^{-3}\right)$ & 1.414 & 1.339 & 1.362 & 1.610 & 1.339 & 1.362 & 1.235 \\
\hline Porosity $\varepsilon_{\mathrm{p}}$ & 0.011 & 0.133 & 0.152 & 0.016 & 0.133 & 0.165 & 0.211 \\
\hline$S_{\mathrm{BET}}\left(\mathrm{m}^{2} \mathrm{~g}^{-1}\right)$ & 41.9 & 228.8 & 244.8 & 97.7 & 228.8 & 277.7 & 364.8 \\
\hline$V_{\mathrm{t}}\left(\mathrm{cm}^{3} \mathrm{~g}^{-1}\right)$ & $7.9 \times 10^{-3}$ & $99.1 \times 10^{-3}$ & $112 \times 10^{-3}$ & $9.7 \times 10^{-3}$ & $99.1 \times 10^{-3}$ & $121 \times 10^{-3}$ & $171 \times 10^{-3}$ \\
\hline
\end{tabular}

lignocellulosic raw material. The increase in the surface area is mainly due to the formation of micropores on cell walls.

\subsection{Electrochemical properties of biochar}

The $\mathrm{pH}$ increased with temperature and residence time, indicating that biochar produced at higher temperature and residence time included structures that are more alkaline. The $\mathrm{pH}$ of the biochar samples ranged from 7.41 to 8.97 (Table 5). This can be related to the increasing ash content at higher temperatures (Cao and Harris, 2010). The main components of ash are salts of alkaline elements ( $\mathrm{Na}, \mathrm{K}, \mathrm{Mg}, \mathrm{Ca})$ [70]. Generally, an increase of $\mathrm{pH}$ supports the degradation of phenolic-OH groups on the biochar surface, increasing the net negative surface charge, thereby increasing the electrostatic attractiveness [7]. At low temperatures $\left(200-300^{\circ} \mathrm{C}\right)$, cellulose and hemicelluloses decompose and form organic acids that decrease the $\mathrm{pH}$ during pyrolysis. The surface functional groups such as carboxylic, lactonic, and phenolics are enhanced during pyrolysis (Table 5), which is also confirmed by other studies $[71,72]$. These functional groups support the sorption capacity of biochar [62]. Especially oxygencontaining groups lead to increased water adsorption capacity due to the role of hydrogen bonds in the adsorption mechanism. Hydrogen bonds can occur between oxygen-containing

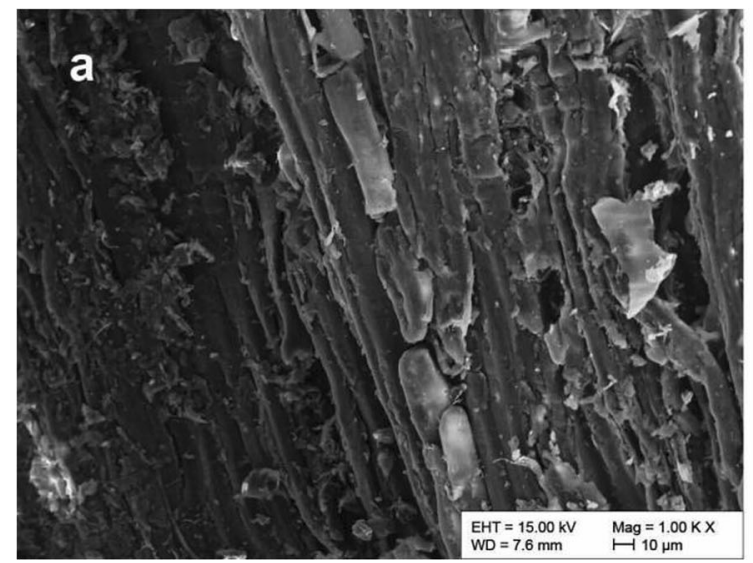

groups on the biochar surface and the adsorbed molecules [73]. The oak sawdust biochar had more alkaline than acidic functional groups; they represent 2.107 and $0.175 \mathrm{mmol} / \mathrm{g}$ at $600{ }^{\circ} \mathrm{C}$, respectively (Table 5). In addition, the acidic functional groups decreased, while the basic functional groups increased with elevating temperature. Among the acidic groups, the carboxylic groups accounted for 25.64-64.71\%, lactone groups $23.36-53.3 \%$, and phenol groups $6.3-50.0 \%$.

\subsection{Hydraulic properties}

The water which is available to plants is adsorbed in soil macro- and mesopores. The main factors that affect the water holding capacity (WHC) of biochar are surface functional groups, total pore volume, porous structure, and surface area [68]. Therefore, the pyrolysis temperature and the holding time are essential parameters that influence the WHC of biochar. The WHC of the obtained biochar samples were 1.16, 1.35 , and $1.49 \mathrm{~mL} \mathrm{~g}^{-1}$ for biochar samples produced at 400 , 500 , and $600{ }^{\circ} \mathrm{C}$, respectively. For prolonged residence times at $500{ }^{\circ} \mathrm{C}$, WHC increased slightly up to 1.39 from $1.12 \mathrm{~mL}$ $\mathrm{g}^{-1}$ while residence time was changing to 120 from $15 \mathrm{~min}$ as a result of the pore formation through volatilization during the long residence time. According to the results, it can be seen that the pyrolysis temperature is more effective than residence

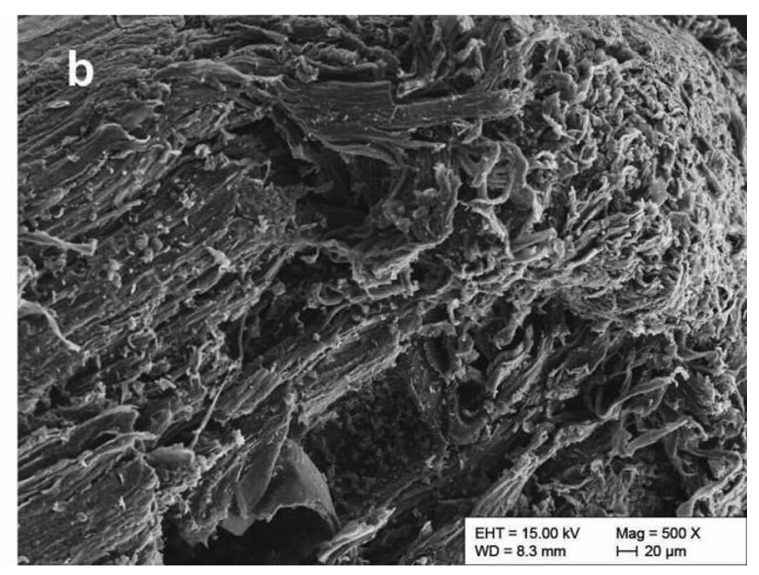

Fig. 4 SEM images of oak sawdust (a) and biochar (b) obtained at $600{ }^{\circ} \mathrm{C}$ and 30 min residence time 
Table $5 \mathrm{pH}$ and surface functional groups $\left(\mathrm{mmol} \mathrm{g}^{-1}\right)$ of biochar samples

\begin{tabular}{|c|c|c|c|c|c|c|c|}
\hline & $\mathrm{pH}$ & Acidic & Lactones & Carboxylics & Phenolics & Basic & Total \\
\hline \multicolumn{8}{|c|}{ Temperature (30 min) } \\
\hline $400^{\circ} \mathrm{C}$ & 7.41 & 0.784 & 0.392 & 0.198 & 0.194 & 1.792 & 2.576 \\
\hline $500^{\circ} \mathrm{C}$ & 7.73 & 0.300 & 0.019 & 0.124 & 0.156 & 2.047 & 2.347 \\
\hline $600^{\circ} \mathrm{C}$ & 8.97 & 0.175 & 0.021 & 0.111 & 0.042 & 2.107 & 2.282 \\
\hline \multicolumn{8}{|c|}{ Residence time $\left(500^{\circ} \mathrm{C}\right)$} \\
\hline $15 \mathrm{~min}$ & 7.54 & 0.387 & 0.023 & 0.171 & 0.193 & 2.020 & 2.407 \\
\hline $30 \mathrm{~min}$ & 7.73 & 0.300 & 0.019 & 0.124 & 0.156 & 2.047 & 2.347 \\
\hline $60 \mathrm{~min}$ & 8.47 & 0.250 & 0.081 & 0.114 & 0.128 & 2.103 & 2.353 \\
\hline $120 \mathrm{~min}$ & 8.73 & 0.200 & 0.066 & 0.099 & 0.094 & 2.139 & 2.339 \\
\hline
\end{tabular}

time on WHC. The highest capacity was observed at $600{ }^{\circ} \mathrm{C}$, where the $S_{\mathrm{BET}}$ was relatively low. This result confirmed that surface area was not the only criterion for high WHCs, whereas other factors such as porous structure and oxygencontaining surface functional groups also affect the WHC significantly [73]. Our results indicate that the surface functional group ratios contributed to the differences in WHC since samples with the highest share of carboxylic and therefore hydrophilic groups did not represent high WHC. This confirms the findings of a recent study by [74].

\section{Conclusions}

In this study, we confirm that oak wood sawdust, as a lignocellulosic raw material, resembles an excellent feedstock for biochar production based on proximate, component, and nutrient analysis. Oak wood biochar can be considered as a valuable soil amendment, and its properties can be engineered by setting particular pyrolysis conditions. Final temperature and residence time are critical pyrolysis conditions in determining biomass conversion and biochar characteristics. The environmental properties of biochar that are widely affected by pyrolysis temperature and residence time are (1) contents of ash and fixed carbon; (2) elemental composition CHNO, especially carbon content; aromaticity; (3) surface area; total pore volume; (4) $\mathrm{pH}$; surface acidity; cation exchange capacity; functional groups and their ratios; (5) water holding capacity; and (6) nutrient content. The physical, chemical, and hydraulic properties of the biochar was observed with instrumental techniques and its properties were investigated by using state-of-the-art analytical and instrumental techniques. Pyrolysis temperature was found to be the essential parameter defining the agronomic characteristics of biochar produced by slow pyrolysis of woody biomass. The $\mathrm{pH}$ and alkaline functional groups increased with the increasing pyrolysis temperature; thus, it provides low surface acidity. Carbon content, micronutrient content, and recalcitrance increased with increasing pyrolysis temperature from 400 to $600{ }^{\circ} \mathrm{C}$. Also, BET surface area and water holding capacity were found larger at higher temperatures; thus, it offers enhanced porosity. In contrast, biochar yield, acidity, and surface functional groups decreased at higher temperatures. Low residence time results in higher char yield, with greater amounts of volatiles and oxygen content; thus, it provides higher surface functional groups. Conversely, longer residence time generates more aromatic, alkaline, and micro-porous biochar. We found that the optimal conditions for slow pyrolysis lie between $500-600^{\circ} \mathrm{C}$ and $60-120^{\circ} \mathrm{min}$ when taking into account the key properties of biochar for soil amendment.

Oak wood (Quercus sp.), which is widely grown in Turkey and has several industrial applications, has been shown to be a suitable feedstock material for biochar production. As a biowaste of forestry and timber industry, the sawdust is usually used directly as solid fuel. Alternative utilization of biowastes as sustainable feedstock in agricultural and forestry applications [11] is an important research subject with a life cycle and carbon sequestration perspective. Oak sawdust biochar can be used to address some of the challenges that Mediterranean soils are facing. As a result, together with the stable regional availability of this feedstock, biochar production can be a viable option for adding value to sawdust, while contributing to carbon sequestration.

Funding information Open access funding provided by University of Natural Resources and Life Sciences Vienna (BOKU).This study was funded by the Anadolu University Scientific Research Council (Project Number: 1502F073).

Data availability All data are available upon request

\section{Compliance with ethical standards}

Conflict of interest The authors declare that they have no conflict of interest.

Open Access This article is licensed under a Creative Commons Attribution 4.0 International License, which permits use, sharing, adaptation, distribution and reproduction in any medium or format, as long as you give appropriate credit to the original author(s) and the source, provide a link to the Creative Commons licence, and indicate if changes were made. The images or other third party material in this article are included in the article's Creative Commons licence, unless indicated otherwise in a 
credit line to the material. If material is not included in the article's Creative Commons licence and your intended use is not permitted by statutory regulation or exceeds the permitted use, you will need to obtain permission directly from the copyright holder. To view a copy of this licence, visit http://creativecommons.org/licenses/by/4.0/.

\section{References}

1. Kwapinski W, Byrne CM, Kryachko E et al (2010) Biochar from biomass and waste. Waste Biomass Valor 1(2):177-189

2. Giudicianni P, Cardone G, Ragucci R (2013) Cellulose, hemicellulose and lignin slow steam pyrolysis: thermal decomposition of biomass components mixtures. J Anal Appl Pyrolysis 100:213-222

3. Tan Z, Yuan S (2019) The effect of preparing temperature and atmosphere on biochar's quality for soil improving. Waste Biomass Valor 10(5):1395-1405

4. Freddo A, Cai C, Reid BJ (2012) Environmental contextualisation of potential toxic elements and polycyclic aromatic hydrocarbons in biochar. Environ Pollut 171:18-24

5. Bruckman VJ, Apaydın Varol E, Uzun BB, Liu J (2016) Biochar: a regional supply chain approach in view of climate change mitigation. Cambridge University Press, Cambridge

6. El-Naggar A, Lee SS, Rinklebe J et al (2019) Biochar application to low fertility soils: a review of current status, and future prospects. Geoderma 337:536-554

7. Nanda S, Dalai AK, Berruti F, Kozinski JA (2016) Biochar as an exceptional bioresource for energy, agronomy, carbon sequestration, activated carbon and specialty materials. Waste Biomass Valor 7(2):201-235

8. Ahmad M, Rajapaksha AU, Lim JE, Zhang M et al (2014) Biochar as a sorbent for contaminant management in soil and water: a review. Chemosphere 99:19-33

9. Tan XF, Liu SB, Liu YG et al (2017) Biochar as potential sustainable precursors for activated carbon production: multiple applications in environmental protection and energy storage. Bioresour Technol 227:359-372

10. Chen D, Li Y, Cen K, Luo M, Li H, Lu B (2016) Pyrolysis polygeneration of poplar wood: effect of heating rate and pyrolysis temperature. Bioresour Technol 218:780-788

11. Bruckman VJ, Pumpanen J (2019) Chapter 17 - Biochar use in global forests: opportunities and challenges. In: Busse M, Giardina CP, Morris DM, Page-Dumroese DS. Developments in Soil Science, vol.36. Elsevier, pp 427-453

12. Ren N, Tang Y, Li M (2018) Mineral additive enhanced carbon retention and stabilization in sewage sludge-derived biochar. Process Safety Environ Protect 115:70-78

13. Han L, Ro KS, Wang Y, Sun K, Sun H, Libra JA, Xing B (2018) Oxidation resistance of biochars as a function of feedstock and pyrolysis condition. Sci Total Environ 616:335-344

14. Zhang Y, Ma Z, Zhang Q, Wang J et al (2017) Comparison of the physicochemical characteristics of bio-char pyrolyzed from moso bamboo and rice husk with different pyrolysis temperatures. Bioresour Technol 12(3):4652-4669

15. Conti R, Fabbri D, Vassura I, Ferroni L (2016) Comparison of chemical and physical indices of thermal stability of biochars from different biomass by analytical pyrolysis and thermogravimetry. $\mathrm{J}$ Anal Appl Pyrolysis 122:160-168

16. Windeatt JH, Ross AB, Williams PT, Forster PM et al (2014) Characteristics of biochars from crop residues: potential for carbon sequestration and soil amendment. J Environ Manag 146:189-197
17. Wang J, Xiong Z, Kuzyakov Y (2016) Biochar stability in soil: meta-analysis of decomposition and priming effects. GCB Bioenergy 8(3):512-523

18. Wiedemeier DB, Brodowski S, Wiesenberg GL (2015) Pyrogenic molecular markers: Linking PAH with BPCA analysis. Chemosphere 119:432-437

19. Crombie K, Mašek O, Sohi SP, Brownsort P, Cross A (2013) The effect of pyrolysis conditions on biochar stability as determined by three methods. GCB Bioenergy 5(2):122-113

20. Harvey OR, Kuo LJ, Zimmerman AR, Louchouarn P et al (2012) An index-based approach to assessing recalcitrance and soil carbon sequestration potential of engineered black carbons (biochars). Enviro Sci Technol 46(3):1415-1421

21. Titiladunayo IF, McDonald AG, Fapetu OP (2012) Effect of temperature on biochar product yield from selected lignocellulosic biomass in a pyrolysis process. Waste Biomass Valor 3(3):311-318

22. McBeath AV, Smernik RJ, Schneider MP, Schmidt MW, Plant EL (2011) Determination of the aromaticity and the degree of aromatic condensation of a thermosequence of wood charcoal using NMR. Org Geochem 42(10):1194-1202

23. Zhang J, Liu J, Liu R (2015) Effects of pyrolysis temperature and heating time on biochar obtained from the pyrolysis of straw and lignosulfonate. Bioresour Technol 176:288-291

24. Suárez-Abelenda M, Kaal J, McBeath AV (2017) Translating analytical pyrolysis fingerprints to thermal stability indices (TSI) to improve biochar characterization by pyrolysis-GC-MS. Biomass Bioener 98:306-320

25. Fang Y, Singh B, Singh BP (2015) Effect of temperature on biochar priming effects and its stability in soils. Soil Biol Biochem 80:136145

26. Lee J, Sarmah AK, Kwon EE (2019) Chapter 1 - Production and formation of biochar. In: Ok YS, Tsang DCW, Bolan N, Novak JM. Biochar from Biomass and Waste. Elsevier, pp 3-18

27. Ronsse F (2016) Biochar production. In: Bruckman VJ, Apaydın Varol E, Uzun BB, Liu J (eds) Biochar: a regional supply chain approach in view of climate change mitigation. Cambridge University Press, Cambridge, pp 199-226

28. Kambo HS, Dutta A (2015) A comparative review of biochar and hydrochar in terms of production, physico-chemical properties and applications. Renew Sustain Ener Rev 45:359-378

29. Jien SH (2019) Chapter 2 - Physical characteristics of biochars and their effects on soil physical properties. In: Ok YS, Tsang DCW, Bolan N, Novak JM Biochar from Biomass and Waste. Elsevier, pp 21-35

30. Zimmerman AR (2010) Abiotic and microbial oxidation of laboratory-produced black carbon (biochar). Environ Sci Technol 44(4):1295-1301

31. Han F, Ren L, Zhang XC (2016) Effect of biochar on the soil nutrients about different grasslands in the Loess Plateau. Catena 137:554-562

32. Kloss S, Zehetner F, Dellantonio A, Hamid R et al (2012) Characterization of slow pyrolysis biochars: effects of feedstocks and pyrolysis temperature on biochar properties. J Environ Qual 41(4):990-1000

33. Cantrell KB, Hunt PG, Uchimiya M, Novak JM, Ro KS (2012) Impact of pyrolysis temperature and manure source on physicochemical characteristics of biochar. Bioresour Technol 107:419428

34. Novak JM, Lima I, Xing B, Gaskin JW et al (2009) Characterization of designer biochar produced at different temperatures and their effects on a loamy sand. Annals Environ Sci 3:195206

35. Wang K, Peng N, Lu G, Dang Z (2018) Effects of pyrolysis temperature and holding time on physicochemical properties of swinemanure-derived biochar. Waste Biomass Valor 11:613-624 
36. Cross A, Sohi SP (2013) A method for screening the relative longterm stability of biochar. Gcb Bioener 5(2):215-220

37. Zornoza R, Moreno-Barriga F, Acosta JA, Muñoz MA, Faz A (2016) Stability, nutrient availability and hydrophobicity of biochars derived from manure, crop residues, and municipal solid waste for their use as soil amendments. Chemosphere 144:122-130

38. Tripathi M, Sahu JN, Ganesan P (2016) Effect of process parameters on production of biochar from biomass waste through pyrolysis: a review. Renew Sustain Ener Rev 55:467-481

39. TOD (The Foresters' Association of Turkey) (2019) Türkiye Ormancılığı: 2019. Kuban Matbaacılık Yayıncılık, Ankara

40. Yu H, Zou W, Chen J, Chen H et al (2019) Biochar amendment improves crop production in problem soils: a review. J Environ Manag 232:8-21

41. Dhyani V, Bhaskar T (2018) A comprehensive review on the pyrolysis of lignocellulosic biomass. Renew Energy 129:695-716

42. Uygur B, Serengil Y (2016) Carbon sequestration potential of forest biomass in Turkey. In: Bruckman VJ, Apaydın Varol E, Uzun BB, Liu J (eds) Biochar: A Regional Supply Chain Approach in View of Climate Change Mitigation. Cambridge University Press, Cambridge, pp 184-195

43. Li S, Xu S, Liu S, Yang C, Lu Q (2004) Fast pyrolysis of biomass in free-fall reactor for hydrogen-rich gas. Fuel Process Technol 85(810):1201-1211

44. Vamvuka D, Zografos D, Alevizos G (2008) Control methods for mitigating biomass ash-related problems in fluidized beds. Bioresour Technol 99(9):3534-3544

45. Masiá AT, Buhre BJP, Gupta RP, Wall TF (2007) Characterising ash of biomass and waste. Fuel Process Technol 88(11-12):10711081

46. Lapuerta M, Hernández JJ, Pazo A, López J (2008) Gasification and co-gasification of biomass wastes: effect of the biomass origin and the gasifier operating conditions. Fuel Procses Technol 89(9): $828-837$

47. Wei X, Schnell U, Hein KR (2005) Behaviour of gaseous chlorine and alkali metals during biomass thermal utilisation. Fuel 84(7-8): 841-848

48. Tillman DA (2000) Biomass cofiring: the technology, the experience, the combustion consequences. Biomass Bioenergy 19(6): 365-384

49. Liu X, Zhang Y, Li Z, Feng R, Zhang Y (2014) Characterization of corncob-derived biochar and pyrolysis kinetics in comparison with corn stalk and sawdust. Bioresour Technol 170:76-82

50. Crombie K, Mašek O (2015) Pyrolysis biochar systems, balance between bioenergy and carbon sequestration. Gcb Bioener 7(2): 349-361

51. Capareda S (2013) Introduction to biomass energy conversions. CRC press, Boca Raton

52. Wilson F, Tremain P, Moghtaderi B (2018) Characterization of biochars derived from pyrolysis of biomass and calcium oxide mixtures. Energy Fuel 32(4):4167-4177

53. Park HJ, Park YK, Dong JI, Kim JS et al (2009) Pyrolysis characteristics of Oriental white oak: kinetic study and fast pyrolysis in a fluidized bed with an improved reaction system. Fuel Process Technol 90(2):186-195

54. Putun AE, Apaydın E, Putun E (2004) Rice straw as a bio-oil source via pyrolysis and steam pyrolysis. Energy 29(12-15):2171-2180

55. Apaydın-Varol E, Putun AE (2012) Preparation and characterization of pyrolytic chars from different biomass samples. J Anal Appl Pyrolysis 98:29-36

56. EBC (2012) European Biochar Certificate - Guidelines for a Sustainable Production of Biochar. European Biochar Foundation (EBC), Arbaz, Switzerland. http://european-biochar.org. Version 9. 0E of 1st June 2020, Accessed: 04-08-2020
57. Tsai WT, Liu SC, Chen HR, Chang YM, Tsai YL (2012) Textural and chemical properties of swine-manure-derived biochar pertinent to its potential use as a soil amendment. Chemosphere 89(2):198 203

58. Smith JM (1981) Chemical engineering kinetics. McGraw-Hill, New York

59. Tsechansky L, Graber ER (2014) Methodological limitations to determining acidic groups at biochar surfaces via the Boehm titration. Carbon 66:730-733

60. Boehm HP (1963) Investigations of surface oxides of carbon. Angew Chem Int Ed Engl 2(4):221-221. https://doi.org/10.1002/ anie. 196302211

61. Zhao L, Cao X, Zheng W, Wang Q, Yang F (2015) Endogenous minerals have influences on surface electrochemistry and ion exchange properties of biochar. Chemosphere 136:133-139

62. Song W, Guo M (2012) Quality variations of poultry litter biochar generated at different pyrolysis temperatures. J Anal Appl Pyrolysis 94:138-145

63. Bruckman VJ, Yan S, Hochbichler E, Glatzel G (2013) Considerations for sustainable biomass production in quercusdominated forest ecosystems. Biomass Now-Cultivation and Utilization. InTech, Rijeka

64. Tag AT, Duman G, Ucar S, Yanik J (2016) Effects of feedstock type and pyrolysis temperature on potential applications of biochar. J Anal Appl Pyrolysis 120:200-206

65. Hossain MK, Strezov V, Chan KY, Ziolkowski A, Nelson PF (2011) Influence of pyrolysis temperature on production and nutrient properties of wastewater sludge biochar. J Environ Manag 92(1):223-228

66. Manyà JJ, Ortigosa MA, Laguarta S, Manso JA (2014) Experimental study on the effect of pyrolysis pressure, peak temperature, and particle size on the potential stability of vine shootsderived biochar. Fuel 133:163-172

67. Spokas KA (2010) Review of the stability of biochar in soils: Predictability of O:C molar ratios. Carbon Manag 1(2):289-303

68. Yuan H, Lu T, Wang Y, Huang H, Chen Y (2014) Influence of pyrolysis temperature and holding time on properties of biochar derived from medicinal herb (radix isatidis) residue and its effect on soil CO2 emission. J Anal Appl Pyrolysis 110:277-284

69. El-Naggar A, Lee SS, Awad YM, Yang X et al (2018b) Influence of soil properties and feedstocks on biochar potential for carbon mineralization and improvement of infertile soils. Geoderma 332:100 108

70. Fidel RB, Laird DA, Parkin TB (2017) Impact of biochar organic and inorganic carbon on soil $\mathrm{CO} 2$ and $\mathrm{N} 2 \mathrm{O}$ emissions. J Environ Qual 46(3):505-513

71. Wu W, Yang M, Feng Q, McGrouther K et al (2012) Chemical characterization of rice straw-derived biochar for soil amendment. Bioma Bioener 47:268-276

72. Jegajeevagan K, Mabilde L, Gebremikael MT, Ameloot $\mathrm{N}$ et al (2016) Artisanal and controlled pyrolysis-based biochars differ in biochemical composition, thermal recalcitrance, and biodegradability in soil. Bioma Bioener 84:1-11

73. Zhang J, You C (2013) Water holding capacity and absorption properties of wood chars. Energy Fuel 27(5):2643-2648

74. Mao J, Zhang K, Chen B (2019) Linking hydrophobicity of biochar to the water repellency and water holding capacity of biocharamended soil. Environ Pollut 253:779-789

Publisher's Note Springer Nature remains neutral with regard to jurisdictional claims in published maps and institutional affiliations. 